\title{
Correction to: Component Recoverability Analysis in Product Design Using System Dynamic Modelling
}

Novita Sakundarini, Nur Shafieza Riwayat, Christina May May Chin, Eng Hwa Yap, Raja Ariffin Raja Ghazilla, and Salwa Hanim Abdul-Rashid

Correction to: A. H. Hu et al. (eds.), Technologies and Eco-innovation towards Sustainability I, https://doi.org/10.1007/978-981-13-1181-9_10

Dr. Nur Shafieza Riwayat's name had been misspelt in the original version of the book in chapter 10. The author's name has now been corrected.

The updated online version of this chapter can be found at https://doi. org/10.1007/978-981-13-1181-9_10 